\title{
Microbial food webs in the dark: independence of lake plankton from recent algal production
}

\author{
Cesar Daniel ${ }^{1}$, Kelly Gutseit ${ }^{1}$, Alexandre M. Anesio ${ }^{2}$, Wilhelm Granéli ${ }^{1, *}$ \\ ${ }^{1}$ Department of Ecology/Limnology, Lund University, 22362 Lund, Sweden \\ ${ }^{2}$ Institute of Biological Sciences, Edward Llwyd Building, University of Wales, Aberystwyth SY23 3DA, UK
}

\begin{abstract}
We investigated the development of a heterotrophic plankton food web with or without phytoplankton primary production in a long-term ( $>1$ yr) laboratory experiment. Water from 3 Swedish lakes (humic, oligotrophic clearwater, eutrophic) was exposed to low light or kept in total darkness in triplicate $100 \mathrm{l}$ cylinders. Dissolved organic carbon (DOC) dynamics, bacterial growth and biomass of protozoans, rotifers and microcrustaceans were followed over $18 \mathrm{mo}$. In the dark treatments, no primary production was detected and DOC concentrations decreased by between 19 and $27 \%$ (1.3 to $\left.3.2 \mathrm{mg} \mathrm{Cl}^{-1}\right)$. There was bacterial and protozoan growth in the dark during the whole experimental period. However, numbers and production of bacteria, as well as protozoan biomass, were significantly lower in darkness. Dissolved (DOM) and particulate organic matter (POM) initially present in the water (i.e. 18 mo old at the end of the experiment) helped to support substantial metazoan biomasses in dark treatments in the humic and eutrophic waters, but not in the oligotrophic clearwater lake. DOM in the humic water, thus largely of allochthonous origin, gave the highest and most prolonged support to zooplankton living in darkness. Our study indicates that a microbial food web, based on allochthonous organic matter and developing independently from phytoplankton, can act as a link to metazoan zooplankton, especially in oligotrophic humic lakes. These results confirm studies using stable $\mathrm{C}$ isotopes, showing a substantial incorporation of terrestrial carbon into zooplankton.
\end{abstract}

KEY WORDS: Dissolved organic matter $\cdot$ DOM $\cdot$ Bacteria $\cdot$ Microbial food web $\cdot$ Zooplankton $\cdot$ Lake $\cdot$ Terrestrial carbon

Resale or republication not permitted without written consent of the publisher

\section{INTRODUCTION}

Bacterial utilization of detrital organic matter (OM) is significant in pelagic environments. In eutrophic lakes, a large portion of the dissolved organic carbon (DOC) is supplied by algal exudation, grazing activity of zooplankton and breakdown of detritus of autochthonous origin (reviewed by Bertilsson \& Jones 2003). Therefore, bacterial abundance and production usually correlate positively with chlorophyll a (Cole 1999 and references therein, Biddanda et al. 2001), suggesting a direct dependence of bacteria on phytoplankton carbon.

In humic lakes, the restricted light penetration in the water column and/or competition for available phosphorus (Shaw 1994, Jansson 1998) possibly result in a low contribution of phytoplankton to the food web. Input of allochthonous OM (i.e. transported into the system from the watershed or deposited directly onto the lake surface in rain, snow and dry deposition) is necessary to sustain high respiration in numerous lakes (del Giorgio \& Peters 1994). Higher respiration than production $(\mathrm{P} / \mathrm{R}<1)$ in the epilimnion is a common feature among the majority of the world's lakes and implies utilization of allochthonous DOC (del Giorgio \& Peters 1994, Cole 1999).

In oligotrophic clearwater lakes, the reduced autotrophic production and low inputs of allochthonous DOC (Karlsson et al. 2001) may limit the energy transfer through the microbial loop. Allochthonous DOC can still be the dominant energy source for bacteria in moderately to highly oligotrophic clearwater lakes 
(Laybourn-Parry et al. 1994, Jonsson et al. 2001, Karlsson et al. 2002). However, bacterial biomass production is low due to the low input and refractory characteristic of organic carbon (Karlsson et al. 2001), affecting growth of predatory zooplankton.

Stable isotope signatures of planktonic organisms can provide direct evidence for utilization of allochthonous dissolved OM (DOM) in lake food webs. Grey et al. (2001) assessed the relative importance of allochthonous carbon to zooplankton by looking at stable isotope signatures of phytoplankton, zooplankton and particulate OM (POM) in Loch Ness over an annual cycle. The authors demonstrated that zooplankton relies heavily on allochthonous carbon in Loch Ness during winter and early spring, when the system is loaded with terrestrial inputs. Moreover, incorporation of appreciable allochthonous carbon in zooplankton occurs even during the peak of phytoplankton productivity. In another study, conducted in 2 moderately unproductive lakes (Kritzberg et al. $2004), 35$ to $70 \%$ of the bacterial carbon was estimated to derive from allochthonous sources during summer months. It was evident in this study that recent phytoplankton production alone cannot support bacterial production, even when phytoplankton photosynthesis should be at its annual maximum (Kritzberg et al. 2004).

It is now reasonably well accepted that bacteria assimilate allochthonous $\mathrm{OM}$ and can ultimately support the growth of microcrustaceans (Hessen 1998, Tranvik 1998). However, zooplankton incorporation of terrestrial carbon tells us little about the possibility of allochthonous OM entirely fulfilling the nutritional requirements of bacteria, protozoans and metazoan zooplankton. The efficiency of bacterial assimilation of terrestrial humus has been suggested to be low, possibly due to a low nitrogen and phosphorus content (Jones 1992, Perdue 1998, Peuravouri \& Pihlaja 1999). In addition, diatoms and cryptophytes contain most of the essential fatty acids crucial for zooplankton nutrition, whereas bacteria are generally considered lowquality food sources (Gulati \& DeMott 1997).

In order to assess the nutritional suitability of $\mathrm{OM}$ of various sources and of different 'ages' to subsidize the plankton food web, we followed bacteria and zooplankton cultured in darkness, thus without any input of newly produced algal OM. Our aim was to investigate whether a heterotrophic food web can exist for longer periods ( $>1 \mathrm{yr}$ ) when maintained exclusively by the OM initially present in lake waters with distinct DOC contents and trophic status. We therefore collected water from a brown-colored oligotrophic, a clearwater oligotrophic and a eutrophic lake and placed it under low light (allowing algal photosynthesis) or in complete darkness for $1.5 \mathrm{yr}$.
We tested the hypothesis that metazooplankton can survive and reproduce independently from recent particulate and dissolved algal production (i.e. in darkness) for a period longer than a year in humic and eutrophic water. With respect to the oligotrophic clearwater, we hypothesized that metazooplankton would be absent in darkness, due to low DOC and nutrient levels, limiting the microbial food web in the absence of recent inputs of phytoplankton exudates. We compared results from the 'dark' treatments with 'low light' treatments. The treatment exposed to low light should correspond to a situation in which there is a moderate contribution of phytoplankton to the food web. We further hypothesized that 'fresh' phytoplankton POM and phytoplankton exudation of DOM are not quantitatively substitutable by aged or allochthonous OM. Thus, we expected algae to support higher biomasses of proto- and metazooplankton in the treatments exposed to low light.

\section{MATERIALS AND METHODS}

Three lakes differing in chlorophyll $a$ ( $\operatorname{chl}$ a) and DOC concentrations were chosen in southern Sweden: a humic, an oligotrophic clearwater and a eutrophic lake (see Table 1). At the time the water was collected (March 2001), temperatures in the water were 1.2, 2.9 and $3.9^{\circ} \mathrm{C}$ in the humic, clearwater and eutrophic lakes, respectively. The sampling date was chosen to maximize the time that the lakes were exposed to low winter temperature and poor light due to snow cover and ice, probably causing primary production to be minimal during the 4 previous months. However, because both snow and ice disappeared a couple of weeks before sampling in the eutrophic lake (located south of the other 2 lakes), recent (post-winter) autochthonous production occurred in this lake in the form of a diatom bloom.

The water was collected from each lake by transferring 10001 into pre-rinsed polyethylene tanks with the help of a gasoline-driven pump. On return to the laboratory (within $3 \mathrm{~h}$ ), the water was randomly distributed into six $100 \mathrm{l}$ polyethylene cylinders for each lake $(1 \mathrm{~m}$ deep and $0.37 \mathrm{~m}$ inner diameter). When filling the cylinders, the water was filtered through a $250 \mu \mathrm{m}$ mesh plankton net to remove large particles and organisms (such as small fish, insects etc.), but allowing the presence of both phyto- and zooplankton. Each set of 6 cylinders was distributed in 2 triplicated treatments: low light conditions (L treatment) and complete darkness (D treatment). The abbreviations E, C and $\mathrm{H}$ will be used throughout the text to refer to the eutrophic, the clearwater oligotrophic and the humic oligotrophic lakes, respectively. The following abbre- 
viations refer to combinations of water type and light treatment: EL, ED, CL, CD, HL and HD.

The cylinders were randomly distributed in a temperature-controlled room, initially adjusted to $7.5^{\circ} \mathrm{C}$ $\left( \pm 1^{\circ} \mathrm{C}\right)$, in order to keep the temperatures similar to those recorded during sampling. After Day 180, the temperature was gradually increased $\left(6^{\circ} \mathrm{C} \mathrm{wk}^{-1}\right)$ until it reached $20^{\circ} \mathrm{C}\left( \pm 1^{\circ} \mathrm{C}\right)$, the typical summer temperature of surface water in southern Swedish lakes. The temperature was kept at $20^{\circ} \mathrm{C}$ until the end of the experiment (i.e. Day 540). The adopted temperature regime falls within the range (approximately 2 to $25^{\circ} \mathrm{C}$ ) to which the epilimnia of the lakes are subjected over an annual cycle.

The cylinders in the D treatment were wrapped with a double layer of thick paper in order to ensure total darkness. In the L treatments, photosynthetically active radiation (PAR) was provided by Cool White lamps (Osram L $36 \mathrm{~W} / 21-840) 12 \mathrm{~h} \mathrm{~d}^{-1}$. The amount of light, just above the water surface $(\sim 0.02 \mathrm{~m})$, was $9.5 \mathrm{~W}$ $\mathrm{m}^{-2}$, roughly corresponding to $10 \%$ of the measured intensity of solar radiation around noon on a clear spring day in southern Sweden $\left(54^{\circ} \mathrm{N}\right)$. The water was mixed every $3 \mathrm{~d}$ and also before each sampling using a Secchi disk. The walls of the cylinders were cleaned once a week with a brush to avoid growth of attached organisms. Cleaning and sampling in the dark treatment was carried out in nearly complete darkness, never with direct incident light. All glassware used during the sampling had been rinsed in acid $(10 \%$ $\mathrm{HCl}$ ) and Milli- $\mathrm{Q}^{\circledR}$ water.

Primary production (PP) measurements were conducted on 5 occasions during the experiment: Days 0 , 30, 80, 280 and 540. PP was estimated using the ${ }^{14} \mathrm{C}$ incorporation method (Wetzel \& Likens 2003). Pyrex glass bottles with $60 \mathrm{ml}$ capacity and ground glass stoppers were acid-washed, rinsed in Milli- $\mathrm{Q}^{\circledR}$ water and then used for the incubations. Water from each treatment was poured into triplicated light bottles (1 bottle per cylinder). Aliquots of $20 \mu \mathrm{l}$ of $\mathrm{NaH}^{14} \mathrm{CO}_{3}$ (4 $\mu \mathrm{Ci}$ final concentration, $2.11 \mathrm{GBq}^{\mathrm{mmol}}{ }^{-1}$ specific activity, Amersham Pharmacia Biotech) were added to each bottle and the incubation took place $1 \mathrm{~cm}$ below the surface in the respective cylinder from which the water had been taken. Two cylinders from each water type and treatment were randomly chosen for the incubation of duplicated dark control bottles. After $4 \mathrm{~h}$, the bottles were transferred to a cool box and immediately processed. The water from each bottle was filtered through a $0.45 \mu \mathrm{m}$ membrane filter, which was then fixed with formaldehyde fumes. The unincorporated ${ }^{14} \mathrm{C}$-bicarbonate was removed by exposure to concentrated $\mathrm{HCl}$ fumes. Scintillation cocktail (Ecoscint A, Kimberly Research) was then added to the filters in plastic scintillation vials. The ${ }^{14} \mathrm{C}$ activity was counted in a Beckman LS 6500 scintillation counter. PP was measured in the dark treatments on 2 occasions and we did not detect any incorporation of $\mathrm{NaH}^{14} \mathrm{CO}_{3}$. Chl a was used as a measure of the autotrophic plankton biomass. Samples for chl a determination (0.2 to 1 l) were filtered through GF/F filters and kept frozen until analysis (within $1 \mathrm{mo}$ ). Ethanol was used for extraction (Jespersen \& Christoffersen 1987) and absorbances at 665 and $750 \mathrm{~nm}$ were measured with a Beckman DU 650 spectrophotometer.

Bacterial abundance and production were measured on 10 occasions: Days 0, 32, 59, 90, 122, 185, 200, 280, 367 and 540 . For bacterial abundance, water was sampled and preserved with $0.2 \mu \mathrm{m}$-filtered formaldehyde ( $2 \%$ final conc.). Samples were analyzed after SYTO 13 (Molecular Probes) staining, using a FACSort (Becton Dickinson) flow cytometer as described by del Giorgio et al. (1996). Samples were run for 1 min without an internal reference. Instead, the flow rate of $16 \mu \mathrm{l}$ min $^{-1}$ was determined with TruCount ${ }^{\mathrm{TM}}$ beads suspended in Milli- $\mathrm{Q}^{\circledR}$ water. After appropriate threshold and detector voltages were set, the bacterial community was examined on green fluorescence against side scatter plots and counted using the computer software Cell Quest ${ }^{\mathrm{TM}}$ (version 3.1). Bacterial production was measured using the $4,5-{ }^{3} \mathrm{H}$ L-leucine incorporation method (Smith \& Azam 1992). The radiolabeled leucine used was diluted with $20 \mu \mathrm{mol} \mathrm{l}^{-1}$ cold leucine in sterile conditions $\left(11.5 \mathrm{Ci} \mathrm{mmol}^{-1}\right.$ final specific activity). For every treatment, duplicated aliquots of $1.7 \mathrm{ml}$ and a trichloroacetic acid (TCA)-killed control were taken from each cylinder and incubated with a final concentration of $100 \mathrm{nmol}$ leucine $\mathrm{l}^{-1}$ (hot + cold). The incubation was terminated after $1 \mathrm{~h}$ by addition of TCA (5\% final conc.). The bacteria were concentrated in a pellet by centrifugation at $14000 \times g$ for $10 \mathrm{~min}$ and cleaned twice with 5\% TCA and once with $80 \%$ ethanol. The pellet was resuspended in scintillation cocktail (Ecoscint A) and the leucine incorporated into the bacterial biomass was measured in a Beckman LS 6500 scintillation counter.

Flagellate and ciliate biomasses were estimated on Days 0, 80, 280 and 540. Triplicate samples were preserved with Lugol's acid solution and allowed to settle in 2 to $30 \mathrm{ml}$ sedimentation chambers, depending on water type and treatment. The organisms were counted and measured using an inverted microscope, as described by Utermöhl (1958). The entire sample was scanned for ciliates at $100 \times$ magnification, and at least 100 of the most common flagellates were counted at $400 \times$ magnification. At least 10 dominant, 5 common and 1 rare taxa were measured for biovolume, determined by matching the cells to geometric shapes and calculating the volumes. Carbon content was esti-

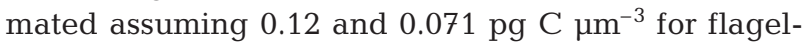


lates and ciliates, respectively (Fenchel 1982, Fenchel \& Finlay 1983).

Samples for determining the biomass of large zooplankton were collected on Days 0, 115, 280 and 540. Nine liters of water were screened through a $45 \mu \mathrm{m}$ mesh plankton net for each cylinder. Samples were preserved with formaldehyde ( $2 \%$ final conc.) and stored at $4^{\circ} \mathrm{C}$. Rotifers and microcrustaceans were identified and quantified using an inverted and a dissecting microscope, respectively. Twenty individuals of each taxon/developmental stage (occasionally 10 individuals for the rare ones) were randomly picked and their body dimensions were measured under appropriate magnification $(200 \times$ for rotifers, otherwise $40 \times$ ). The biovolume of rotifers was calculated according to Ruttner-Kolisko (1977) and carbon biomass obtained following the application of equations suggested in Telesh et al. (1998). Dry weights of microcrustaceans were estimated from the body lengths (Dumont et al. 1975) and carbon biomass obtained using a conversion factor (carbon weight $=45 \%$ dry weight).

DOC concentration was measured on 8 occasions: Days $0,15,60,120,200,280,360$ and 540. Aliquots of $50 \mathrm{ml}$ were filtered through $0.2 \mu \mathrm{m}$ pore cellulose acetate membrane filters. Dissolved inorganic carbon (DIC) was eliminated from the samples by $\mathrm{HCl}$ addition and sparging for $5 \mathrm{~min}$ with $\mathrm{CO}_{2}$-free air. Samples were analyzed using a Shimadzu TOC-5000 total carbon analyzer equipped with an autosampler. Initial absorbances at $254 \mathrm{~nm}$ (Abs254) were measured in filtered water using acid-washed $1 \mathrm{~cm}$ quartz cuvettes and a Beckman DU 650 spectrophotometer. The ratio Abs254/DOC was adopted as an indication of the contribution of allochthonous substances to the DOC pool. Unsaturated bonds, found in a variety of aromatic humic substances (e.g. phenols, benzene rings, carboxylic acids), have maximum absorbance near $254 \mathrm{~nm}$ (Imai et al. 2001), whereas substances of autochthonous origin are predominantly composed of aliphatic, alicyclic structures, indicative of a lipid hydrocarbon source (Leenheer 1994). DIC was determined on the same occasions as PP. Samples were analyzed immediately after collection from the cylinders using the Shimadzu TOC-5000 carbon analyzer.

Repeated-measure ANOVA (rm-ANOVA) was performed in SPSS (version 10.0) to compare bacterial numbers, bacterial production and biomass of different zooplankton groups between L and D (treatment effect). Different water types were also compared within each treatment (L and D). Tukey's honestly significant difference (HSD) test was used when a significant p-value was obtained. Biomasses of flagellates, ciliates, rotifers and microcrustaceans were logtransformed before analysis in order to fulfill the assumptions of normality and homoscedasticity.

\section{RESULTS}

Initial values of DOC-normalized Abs254 indicated a high influence of allochthonous OM in the humic lake (Table 1). Lower values obtained in both oligotrophic clearwater and eutrophic water indicate lower aromatic content, suggesting a smaller contribution from terrestrial OM. Measurements of PP after 15 and $30 \mathrm{~d}$ in darkness (data not shown) and of chl a during the whole experiment (Table 2) confirmed the absence of autotrophic influence (phytoplankton growth) in the D treatments. A maximal PP value of $243 \mu \mathrm{g} \mathrm{C} \mathrm{l}^{-1} \mathrm{~h}^{-1}$ was observed in the eutrophic water on Day 0. In general, $\mathrm{PP}$ and chl $a$ increased in the $\mathrm{L}$ treatment after the temperature was gradually increased from 7 to $20^{\circ} \mathrm{C}$ (after Day 180). This increase was remarkable in HL, where the final PP was $32 \mu \mathrm{g} \mathrm{C}{ }^{-1} \mathrm{~h}^{-1}$ compared to $0.2 \mu \mathrm{g} \mathrm{Cl}^{-1}$ $\mathrm{h}^{-1}$ on Day 0 (Table 2).

A decrease in the DOC concentration was observed during the experiment in the dark treatments. At the end of the experiment, the DOC concentrations found in the D treatments were 78,63 and $81 \%$ of the initial values for humic, clear and eutrophic water, respectively. Conversely, DOC concentration increased to

Table 1. Location and descriptive data of the lakes used in the study (Almestrand \& Lundqvist 1983, Bergvall 1992, Bengtsson 1993, SLU [Sveriges Lantbruks Universitet] database http://info1.ma.slu.se/). Abs254: absorbances at $254 \mathrm{~nm}$

\begin{tabular}{|c|c|c|c|c|c|c|c|}
\hline Lake & Location & $\begin{array}{l}\text { Water residence } \\
\text { time (yr) }\end{array}$ & $\begin{array}{c}\text { DOC } \\
\left(\mathrm{mg} \mathrm{l}^{-1}\right)^{\mathrm{a}}\end{array}$ & $\begin{array}{l}\text { Total N } \\
\left(\mathrm{mg} \mathrm{l}^{-1}\right)\end{array}$ & $\begin{array}{l}\text { Total P } \\
\left(\mu g \mathrm{l}^{-1}\right)\end{array}$ & $\begin{array}{c}\mathrm{Abs} 254 \\
(\mathrm{~nm})^{\mathrm{a}}\end{array}$ & $\begin{array}{l}\text { Abs254 }(\mathrm{nm} \\
\left.\mathrm{DOC}^{-1}\right)^{\mathrm{a}}\end{array}$ \\
\hline $\begin{array}{l}\text { Lake Skärshult } \\
\text { (oligotrophic humic) }\end{array}$ & $\begin{array}{l}63^{\circ} 38^{\prime} 7^{\prime \prime} \mathrm{N} \\
14^{\circ} 21^{\prime} 6^{\prime \prime} \mathrm{E}\end{array}$ & 0.7 & 15 & 0.51 & 10 & 0.667 & 0.044 \\
\hline $\begin{array}{l}\text { Lake Skärlen } \\
\text { (oligotrophic clear) }\end{array}$ & $\begin{array}{l}63^{\circ} 38^{\prime} 3^{\prime \prime} \mathrm{N} \\
14^{\circ} 44^{\prime} 0^{\prime \prime} \mathrm{E}\end{array}$ & 8.4 & 4.3 & 0.26 & 5 & 0.092 & 0.021 \\
\hline $\begin{array}{l}\text { Lake Vomb } \\
\text { (eutrophic) }\end{array}$ & $\begin{array}{l}55^{\circ} 42^{\prime} 3^{\prime \prime} \mathrm{N} \\
13^{\circ} 35^{\prime} 1^{\prime \prime} \mathrm{E}\end{array}$ & 0.6 & 6.7 & 0.76 & 73 & 0.192 & 0.024 \\
\hline
\end{tabular}


168,190 and $133 \%$ of the initial values for humic, clear and eutrophic water in the L treatments (Fig. 1). Bacterial numbers were statistically higher in the $L$ than in the $\mathrm{D}$ treatments for all water types (Tables $3 \& 4$, Fig. 2). Bacterial numbers (cells $\mathrm{ml}^{-1}$ ) ranged from $8 \times$ $10^{5}$ to $3 \times 10^{6}$ in the HD, from $4 \times 10^{5}$ to $2 \times 10^{6}$ in the $\mathrm{CD}$, and from $6 \times 10^{5}$ to $1 \times 10^{7}$ in the ED treatment. Within the D and L treatments, the 3 water types were statistically different from each other regarding bacterial numbers ( $p<0.05$ from Tukey's HSD test), with eutrophic water showing the highest bacterial numbers during most of the experiment. Bacterial production rates varied largely in all water types $(\sim 0$ to $1.5 \mu \mathrm{g} \mathrm{C}^{-1} \mathrm{~h}^{-1}$ ). Rates recorded for $\mathrm{L}$ cylinders were in general significantly higher than those for the D treatments (Table 3). Production rates measured in the D treatments ranged between 22 and $194 \%$ of the values from their respective L treatments (Fig. 2). Increased

Table 2. Means $(\mathrm{n}=3$ ) and standard deviations for primary production ( $\left.\mathrm{PP} ; \mu \mathrm{C} \mathrm{Cl}^{-1} \mathrm{~h}^{-1}\right)$ and chl a $\left(\mu \mathrm{g} \mathrm{l}^{-1}\right)$

\begin{tabular}{|lccccc|}
\hline $\begin{array}{l}\text { Treat- } \\
\text { ment }\end{array}$ & Day 0 & Day 30 & Day 80 & Day 280 & Day 540 \\
\hline PP & & & & & \\
HL & $0.2 \pm 0.0$ & $0.2 \pm 0.0$ & $0.2 \pm 0.0$ & $15 \pm 3.5$ & $32 \pm 5$ \\
CL & $5.1 \pm 0.3$ & $1.3 \pm 0.2$ & $3.0 \pm 0.2$ & $7.1 \pm 1.9$ & $11 \pm 4.2$ \\
EL & $243 \pm 3$ & $32 \pm 5$ & $8.5 \pm 1.4$ & $54 \pm 6$ & $9.5 \pm 6.3$ \\
Chl a & & & & & \\
HL & $0.3 \pm 0.2$ & $0.6 \pm 0.0$ & $0.9 \pm 0.1$ & $44 \pm 8.7$ & $270 \pm 83$ \\
HD & $0.3 \pm 0.2$ & $0.3 \pm 0.1$ & $0.2 \pm 0.0$ & $0.1 \pm 0.0$ & $0.1 \pm 0.0$ \\
CL & $2.3 \pm 0.1$ & $3.4 \pm 0.5$ & $8.2 \pm 1.7$ & $14 \pm 0.6$ & $16 \pm 6.3$ \\
CD & $2.3 \pm 0.1$ & $0.7 \pm 0.1$ & $0.2 \pm 0.0$ & $0.1 \pm 0.1$ & $0.1 \pm 0.0$ \\
EL & $58 \pm 3$ & $82 \pm 7$ & $47 \pm 9$ & $84 \pm 23$ & $125 \pm 76$ \\
ED & $58 \pm 3$ & $8 \pm 0.4$ & $3.7 \pm 0.2$ & $0.9 \pm 0.1$ & $0.4 \pm 0.2$ \\
\hline
\end{tabular}

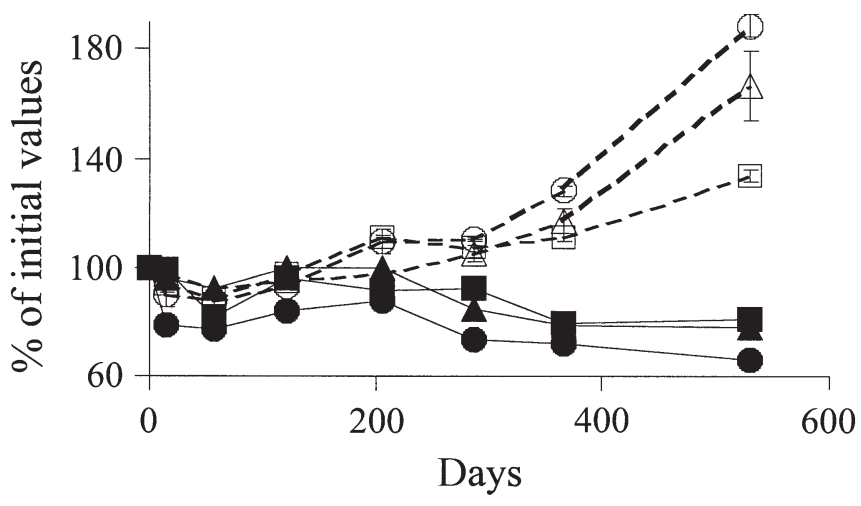

Fig. 1. Deviation from the initial DOC concentration (100\%) in humic (triangles), clearwater (circles) and eutrophic (squares) water types. Empty symbols/dashed lines indicate the light treatments, filled symbols/solid lines correspond to the dark treatments. Error bars represent $\pm 1 \mathrm{SD}(\mathrm{n}=3)$

bacterial production was recorded when the temperature was adjusted to $20^{\circ} \mathrm{C}$.

Both flagellates and ciliates occurred in all D treatments, but significantly higher biomasses were observed in L treatments compared to D, except for ciliates in the humic type (Tables $3 \& 4$ ). The CL treatment showed the highest flagellate biomass, reaching values up to $126 \mu \mathrm{g} \mathrm{C}^{-1}$. No statistical differences were detected in protozoan biomass among the D cylinders (Table 4, Fig. 3). The lack of fresh algal contribution in darkness negatively affected the biomass of microcrustaceans and rotifers. Calanoid copepods and the rotifer Asplanchna sp. did not occur in any of the treatments in darkness (Table 5). Polyarthra sp. only occurred in the ED treatment, whereas Lecane sp. only occurred in the CD treatment. Regarding taxonomic composition,

Table 3. Means ( $\mathrm{n}=3$ ) and standard deviations for numbers and production of bacteria (Bact.), and biomass of flagellates, ciliates, rotifers and microcrustaceans over the whole period of experiment. Values obtained during each sampling time were pooled

\begin{tabular}{|c|c|c|c|c|c|c|}
\hline & \multicolumn{2}{|c|}{ Humic } & \multicolumn{2}{|c|}{ Clearwater } & \multicolumn{2}{|c|}{ Eutrophic } \\
\hline & Light & Dark & Light & Dark & Light & Dark \\
\hline $\begin{array}{l}\text { Bact. numbers } \\
\left(10^{6} \text { cells ml }{ }^{-1}\right)\end{array}$ & $2.1 \pm 0.9$ & $1.5 \pm 0.6$ & $1.4 \pm 0.4$ & $1.0 \pm 0.5$ & $3.7 \pm 2.9$ & $2.9 \pm 2.7$ \\
\hline $\begin{array}{l}\text { Bact. production } \\
\left(\mu \mathrm{g} \mathrm{Cl}^{-1} \mathrm{~h}^{-1}\right)\end{array}$ & $0.36 \pm 0.25$ & $0.27 \pm 0.19$ & $0.40 \pm 0.40$ & $0.27 \pm 0.23$ & $0.64 \pm 0.51$ & $0.36 \pm 0.34$ \\
\hline $\begin{array}{l}\text { Flagellate biomass } \\
\left(\mu \mathrm{C}^{-1}\right)\end{array}$ & $21 \pm 8.6$ & $3.2 \pm 1.7$ & $67 \pm 58$ & $2.8 \pm 2.1$ & $14 \pm 8.8$ & $2.7 \pm 2.5$ \\
\hline $\begin{array}{l}\text { Ciliate biomass } \\
\left(\mu \mathrm{g} \mathrm{C}^{-1}\right)\end{array}$ & $3.3 \pm 3.4$ & $1.6 \pm 1.3$ & $12 \pm 12$ & $1.9 \pm 2.6$ & $17 \pm 11$ & $2.6 \pm 3.8$ \\
\hline $\begin{array}{l}\text { Rotifer biomass } \\
\left(\mu \mathrm{g} \mathrm{C}^{-1}\right)\end{array}$ & $5.1 \pm 7.5$ & Inconstant & $0.7 \pm 0.7$ & $0.2 \pm 0.3$ & $2.8 \pm 4.1$ & Inconstant \\
\hline $\begin{array}{l}\text { Microcrust. biomass } \\
\left(\mu \mathrm{C} \mathrm{C}^{-1}\right)\end{array}$ & $17 \pm 19$ & $1.4 \pm 1.0$ & Inconstant & Absent & $10 \pm 20$ & $0.9 \pm 1.0$ \\
\hline
\end{tabular}


Table 4. p-levels for numbers and production of bacteria (Bact.), biomass of flagellates, ciliates, rotifers and microcrustaceans (Microcrust.) according to repeated measure ANOVA. Treatment effect (light versus dark) was checked for the different water types (humic, clearwater and eutrophic). Differences among water types within light and dark were also analyzed. Significant values at the $5 \%$ level are shown in bold

\begin{tabular}{|lccccc|}
\hline & Humic & Clearwater & Eutrophic & Light & Dark \\
\hline Bact. numbers & $\mathbf{0 . 0 0 3}$ & $\mathbf{0 . 0 0 8}$ & $\mathbf{0 . 0 0 8}$ & $\mathbf{< . 0 0 1}$ & $<\mathbf{0 . 0 0 1}$ \\
Bact. production & $\mathbf{0 . 0 0 5}$ & $\mathbf{0 . 0 0 9}$ & $\mathbf{0 . 0 0 2}$ & $\mathbf{< 0 . 0 0 1}$ & $<\mathbf{0 . 0 0 1}$ \\
Flagellate biomass & $\mathbf{0 . 0 1 0}$ & $\mathbf{0 . 0 0 8}$ & $\mathbf{0 . 0 1 5}$ & $\mathbf{0 . 0 0 7}$ & 0.550 \\
Ciliate biomass & 0.182 & $\mathbf{0 . 0 1 7}$ & $\mathbf{0 . 0 0 6}$ & $\mathbf{0 . 0 1 3}$ & 0.545 \\
Rotifer biomass & Inconstant occur. dark & 0.269 & Inconstant occur. dark & 0.092 & Inconstant occur. H, E \\
Microcrust. biomass & $\mathbf{0 . 0 2 0}$ & Absent dark & 0.052 & (H vs E) & (H vs E) \\
& & & & 0.635 & 0.379 \\
\hline
\end{tabular}

none of the zooplankters was exclusively associated with dark conditions. Fewer taxa were recorded in CD, ED and HD treatments compared to the corresponding L treatments (Table 5). Microcrustaceans were absent

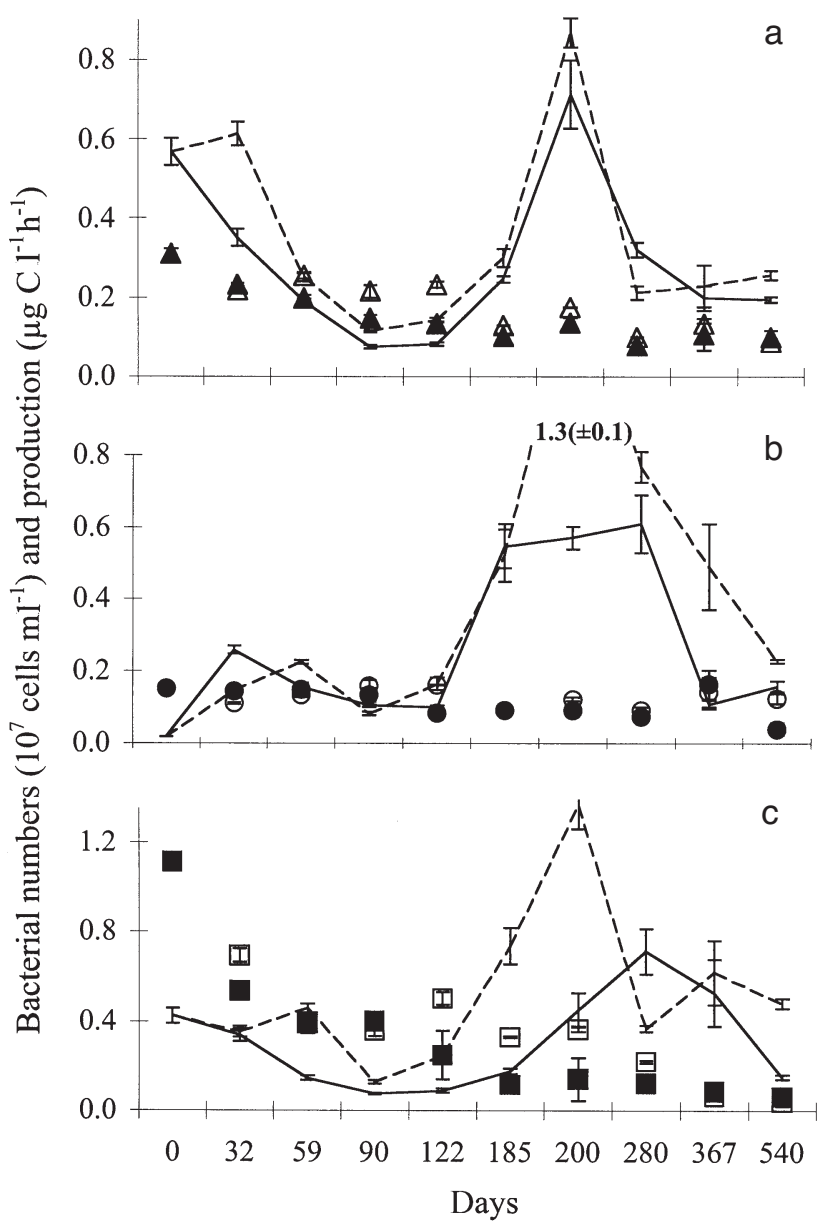

Fig. 2. Bacterial numbers $\left(10^{7}\right.$ cells $\left.\mathrm{ml}^{-1}\right)$ and production $(\mu \mathrm{g} \mathrm{C}$ $\mathrm{l}^{-1} \mathrm{~h}^{-1}$ ) in the (a) humic, (b) clearwater and (c) eutrophic water types. Symbols indicate bacterial numbers, lines indicate bacterial production. Empty symbols/dashed lines indicate the light treatments, filled symbols/solid lines correspond to the dark treatments. Error bars represent $\pm 1 \mathrm{SD}(\mathrm{n}=3)$ in the CD treatment, which was not the case for HD or ED treatments, in which cyclopoid copepods showed high biomasses. A cladoceran of the genus Chydorus co-occurred with cyclopoid copepods in the HD treatment, but the metazoan biomass was significantly lower than in the HL treatment (Tables 3 \& 4, Fig. 4a). In the $\mathrm{L}$ cylinders, rotifers constituted a considerable part of the metazoan biomass, whereas in darkness,

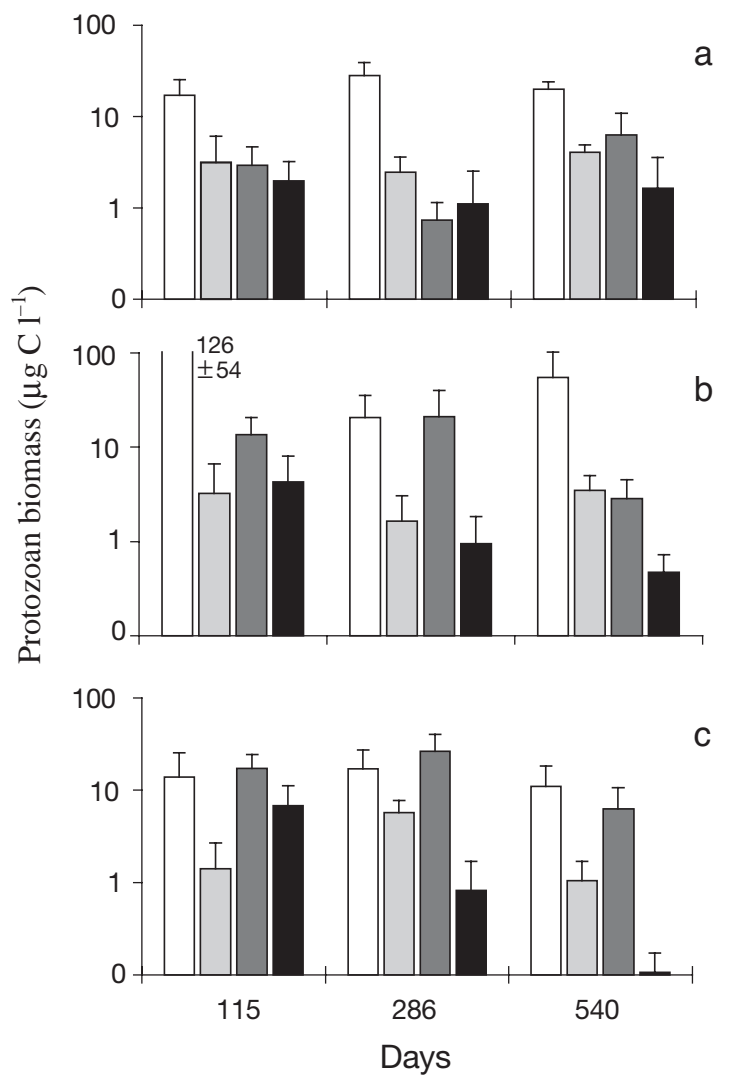

Fig. 3. Protozoan biomass ( $\mu \mathrm{g} \mathrm{Cl}^{-1}$ ) in the (a) humic, (b) clearwater and (c) eutrophic water types: flagellates in light treatments (white); flagellates in dark treatments (pale grey); ciliates in light treatments (grey) and ciliates in dark treatments (black). Error bars represent $+\mathrm{SD}(\mathrm{n}=3)$ 
rotifer biomass was pronounced only for the clearwater (CD), where it decreased towards the end of the experiment (Fig. 4b). Calanoid copepods were important in the EL treatment, but a rotifer belonging to the genus Lecane dominated the community in this treatment at the end of the experiment (Fig. 4c).

Table 5. Metazooplankton recorded in the 3 treatments

\begin{tabular}{|c|c|c|c|c|c|c|}
\hline \multirow[t]{2}{*}{ Taxon } & \multicolumn{2}{|c|}{ Humic } & \multicolumn{2}{|c|}{ Clearwater } & \multicolumn{2}{|c|}{ Eutrophic } \\
\hline & HL & HD & $\mathrm{CL}$ & CD & EL & ED \\
\hline Calanoida & & & & & $\mathrm{x}$ & \\
\hline Cyclopoida & $\mathrm{x}$ & $\mathrm{x}$ & $\mathrm{x}$ & & $\mathrm{x}$ & $\mathrm{x}$ \\
\hline Cladocera & $\mathrm{x}$ & $\mathrm{x}$ & & & $\mathrm{x}$ & $\mathrm{x}$ \\
\hline Keratella quadrata & $\mathrm{x}$ & $\mathrm{x}$ & $\mathrm{x}$ & $\mathrm{x}$ & $\mathrm{x}$ & $\mathrm{x}$ \\
\hline Keratella cochlearis & $\mathrm{x}$ & $\mathrm{x}$ & $\mathrm{x}$ & $\mathrm{x}$ & $\mathrm{x}$ & \\
\hline Kellikottia sp. & $\mathrm{x}$ & $\mathrm{x}$ & $\mathrm{x}$ & $\mathrm{x}$ & $\mathrm{x}$ & $\mathrm{x}$ \\
\hline Polyarthra sp. & $\mathrm{x}$ & & $\mathrm{x}$ & & & $\mathrm{x}$ \\
\hline Lecane sp. & $\mathrm{x}$ & & & $\mathrm{x}$ & $\mathrm{x}$ & \\
\hline Asplanchna sp. & & & $\mathrm{x}$ & $\mathrm{x}$ & $\mathrm{x}$ & \\
\hline Brachionus sp. & & & & & $\mathrm{x}$ & \\
\hline Filinia sp. & & & & & $\mathrm{x}$ & $\mathrm{x}$ \\
\hline
\end{tabular}

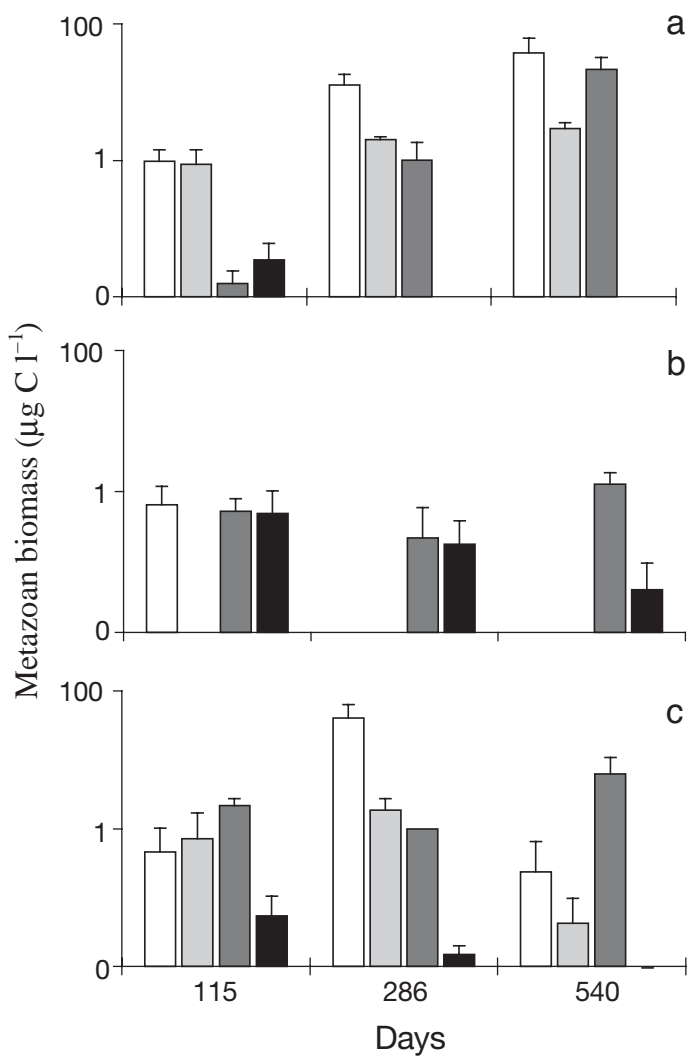

Fig. 4. Metazoan biomass ( $\mu \mathrm{C} \mathrm{Cl}^{-1}$ ) in the (a) humic, (b) clearwater and (c) eutrophic water types: microcrustaceans in light treatments (white); microcrustaceans in dark treatments (pale grey); rotifers in light treatments (grey) and rotifers in dark treatments (black). Error bars represent $+\mathrm{SD}(\mathrm{n}=3)$

\section{DISCUSSION}

\section{Bacteria}

Recently produced phytoplankton DOM represented an additional carbon source to bacteria apart from the allochthonous and 'older' autochthonous DOM that were the sole carbon sources in the D treatments. Superior bacterial production in the L treatments of all water types suggests that recent algal DOM was channeled into the microbial food web. Large differences in bacterial production among $\mathrm{D}$ treatments were not observed, possibly due to depletion of easily available OM irrespective of lake type, as a little initial utilization of DOC occurred. After Day 200, bacterial production increased in all D treatments, probably resulting from a stimulation of DOC decomposition by the gradual increase in temperature from 7.5 to $20^{\circ} \mathrm{C}$. At the end of the experiment, the DOC concentrations had decreased to a substantial extent in all D treatments, despite the contrasting DOC concentrations and water color. Consumption of DOC that had not been replenished with new algal or terrestrial inputs for several months illustrates the importance of slow-degrading DOM for bacterial production.

Bacteria in the humic water relied on other sources of organic carbon than those derived from recent phytoplankton photosynthesis, as indicated by higher levels of bacterial production compared to PP in the L treatment during the first 3 mo of the experiment. Because PP was only measured at the surface, results cannot be expressed on an areal basis. Since PP decreases strongly with depth, calculations on an areal basis would result in an even lower support of bacterial production by phytoplankton. This suggests that bacteria may grow largely independently from phytoplankton, especially in humic water, where the absence of fresh inputs of OM for periods longer than a year would not affect bacterial production as much as in other water types.

Although allochthonous DOM seems to be continually utilized by bacteria for several months, hydraulic characteristics of the system will finally determine its fate after entering a lake. In Lake Örträsket, high discharge can stimulate bacterial production by introducing 'fresh' degradable OM of allochthonous origin (Jansson et al. 1999). Allochthonous carbon assimilated by bacteria is transferred to higher levels in the food chain via mixotrophic flagellates. Because Lake Örträsket has a water residence time of 100 d (Jansson et al. 1999), a more prolonged effect of allochthonous DOM on bacterial growth in this lake is presumed to be negligible.

The high chl a concentration in the eutrophic lake at the time the water was sampled suggests that substan- 
tial phytoplankton PP had occurred (Table 2). The high initial biomass of the diatom Cyclotella sp. in the lake probably caused formation of labile DOM and POM, resulting in high bacterial production in both EL and ED treatments. However, bacterial production decreased considerably in the ED treatment after the first month, indicating that the contribution of labile DOM to bacteria had a limited duration (Fig. 2c). Experiments have shown that labile (saccharides, amino acids and their oligomers) and semi-labile (polysaccharides, polypeptides, nucleic acids) DOM, accessible to bacteria because of their regular polymeric structure, normally lasts for periods of up to $1 \mathrm{mo}$ (del Giorgio \& Davis 2003, Sinsabaugh \& Foreman 2003). Since the duration of our experiment was longer than $1 \mathrm{yr}$, the OM source important for the heterotrophic food chain in darkness could not be predominantly composed of the labile substances that were initially present.

\section{Protozoa}

The ability to combine phagotrophy and photosynthesis (i.e. mixotrophy) can be important among planktonic protists (Jones 2000). Although potentially mixotrophic flagellates and ciliates may have occurred in D treatments, they were not able to grow autotrophically. Therefore, all protozoans occurring in D treatments were functionally heterotrophic and relied on bacterial carbon assimilated from DOM initially present in the water. On the other hand, active mixotrophs may have occurred to a significant extent in $\mathrm{L}$ treatments. The biomass of flagellates and ciliates was strongly affected by the treatment, as several-fold increases were found in L treatments relative to $\mathrm{D}$, except for ciliates in the humic water type. Even though the light level provided in our L treatments was low, phototrophic growth of mixotrophic flagellates and ciliates probably contributed to higher protozoan biomass in the L treatments. At a similar light intensity, Pålsson \& Daniel (2004) observed that photosynthesis by the widely occurring flagellated mixotroph Poterioochromonas malhamensis could support $80 \%$ of the gain in cell carbon when bacterial abundances were low. Nevertheless, higher flagellate biomass in the L treatments may also partly be a result of ingestion of bacteria growing in the presence of both 'old' and algal-derived DOM.

Although bacterial numbers and production were lowest in the CD treatment, the levels of protozoan biomass in $\mathrm{CD}, \mathrm{HD}$ and $\mathrm{ED}$ treatments were similar (Tables $3 \& 4$ ). This is possibly associated with negligible predation pressure on both flagellates and ciliates in the CD treatment, as the metazooplankton biomass was found to be the lowest among all treatments. The difference in protozoan biomass among L treatments was probably not due to differences in the availability of food resources, as higher values were recorded for $\mathrm{CL}$ in comparison with EL and HL treatments. The comparatively low numbers and production of bacteria in the CL treatment were expected to support a lower protozoan biomass. On the other hand, extensive metazoan occurrence suggests predation control of protozoans in HL and EL treatments, whereas higher accumulation of protozoan biomass was possible in the CL treatment.

\section{Metazoa}

Although metazoans were present in the D treatments, even after $1.5 \mathrm{yr}$, metazoan biomass was noticeably higher in the L treatments. However, even without recently produced phytoplankton OM, metazoans survived in a detrital food chain based on DOM of terrestrial origin or recycled autochthonous DOM which had not been replenished for more than a year. There were large standard deviations in metazoan biomass, especially in the L treatments of all water types (Table 3). Therefore, differences in metazoan biomass between $\mathrm{L}$ and $\mathrm{D}$ treatments were non-significant in the clear and eutrophic waters (rotifers in oligotrophic clearwater, otherwise microcrustaceans). Conversely, the $\mathrm{p}$-values for the rm-ANOVA indicated statistically significant differences in microcrustacean biomass between $\mathrm{L}$ and $\mathrm{D}$ treatments for the humic water (Table 4).

Adult microcrustaceans were absent in the oligotrophic clearwater, regardless of treatment. Even though nauplii occurred in both L and D treatments, their contribution to metazoan biomass was not substantial in the oligotrophic clearwater, probably due to a reduced density of suitable prey. On the other hand, food availability for rotifers was perhaps higher than for nauplii, as rotifers occurred in the oligotrophic clearwater during the whole experiment (Fig. 4b). Occurrence of rotifers in the $\mathrm{CD}$ treatment contradicts our hypothesis regarding the oligotrophic clearwater and suggests that metazooplankton were in fact linked by an active bacterial loop to OM without recent input of phytoplankton carbon. It is unclear whether the rotifers in the CD treatment (Keratella spp. and Kellikottia sp.) fed only on protozoans, or also on fine detritus or bacteria, as their selectivity for food is poor (Pourriot 1977).

Maximum zooplankton biomass in the HD treatment was found at the end of the experiment (Fig. 5a). Cyclopoid copepods and the cladoceran genus Chydorus were recorded on the last sampling occasion, likely supported by microbes that assimilated OM of alloch- 
thonous origin initially present in the water. The rather small cladoceran Chydorus sp. is probably an effective feeder on small protozoans, which are considered highquality food (Burns \& Schallenberg 2001). The zooplankton may also have fed partially on detritus containing attached bacteria (Hessen 1998). Indeed, the copepods showed a mixed feeding behavior under the dissection microscope, both intercepting smaller zooplankton and exploiting detrital particles. Regardless of the relative contribution of particulate detritus as food for zooplankton in the HD treatment, OM that was initially present, or that had been recycled during the course of the experiment and assimilated by microbes, constituted the exclusive source of zooplankton carbon. Therefore, our hypothesis that metazooplankton can grow and reproduce independently from recent phytoplankton production was confirmed for the humic water. The large DOC pool in the humic water, compared to that in the oligotrophic clearwater, seemed to
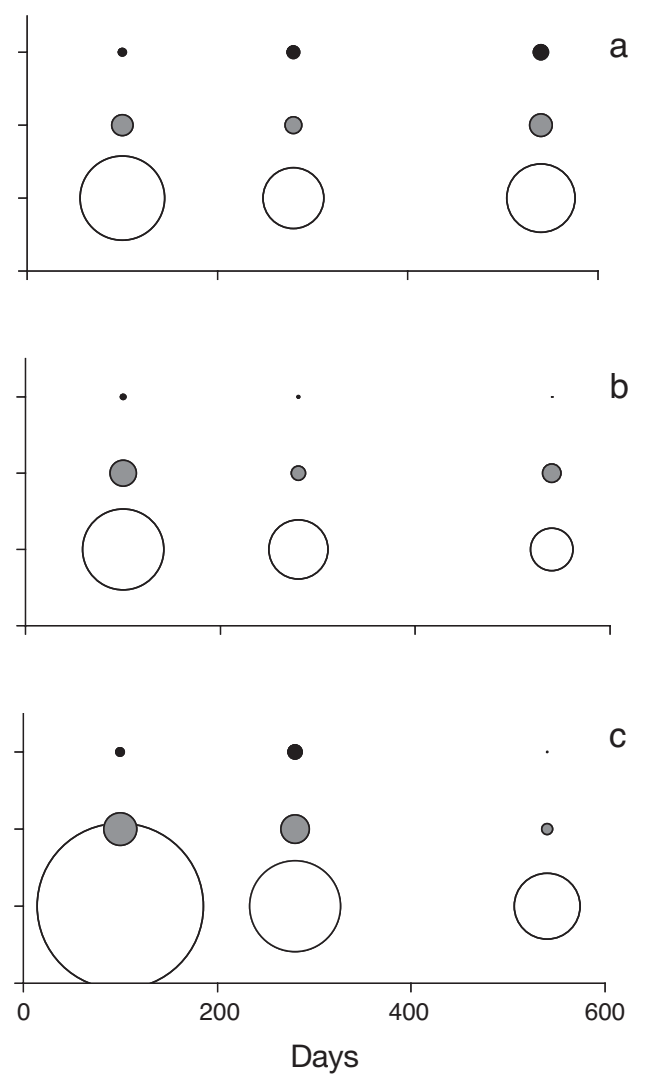

Fig. 5. Heterotrophs in the dark treatments. Circle sizes represent mean biomass of bacteria (empty circles), protozoa (gray circles) and metazoa (black circles) throughout the experiment. Circle sizes are also comparable among and within (a) humic, (b) clearwater and (c) eutrophic water types (absolute values for protozoan and metazoan biomasses are shown in Figs. $3 \& 4$ ). For all water types the numbers of bacteria shown in Fig. 2 were multiplied by a fixed value of

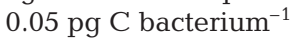

be important, not only from the perspective of supporting a food web for longer periods (Fig. 5a), but also for providing conditions allowing the existence of largebodied predatory copepods (Fig. 4a).

We hypothesized that metazooplankton in the eutrophic water in darkness could be maintained by the OM that was initially present. A fraction of this OM pool would be of phytoplankton origin (due to the presence of active diatoms at the time of sampling) and thus a good substrate for bacteria, although this source would eventually be exhausted. By the end of the experiment, metazooplankton nearly collapsed in the ED treatment, as the biomass of cladocerans and rotifers was very low (Fig. 5c). The disappearance of copepods and the low final biomass of metazooplankton in the ED compared to HD treatment suggest a comparatively less prolonged ability of DOM to support zooplankton. The high bacterial production in the ED compared to HD treatment (Table 3) possibly resulted from more rapid utilization of degradable DOM in increased nutrient concentrations, which may have depleted carbon sources to fuel the microbial food web. Reported values of total nitrogen and phosphorus (Table 1), in addition to the chl a levels and PP rates in the light treatments (Table 2), suggest that the eutrophic water had the highest trophic status among the water types used in our experiment. Since no phosphorus or nitrogen additions were carried out, low nutrient availability might have limited bacterial utilization of DOM in the HD treatment more than it did in the ED treatment. Therefore, survival of microcrustaceans in the HD treatment was associated with the size of the DOC pool, which was slowly utilized by bacteria, as nutrients could only be recycled through DOM mineralization and zooplankton excretion. Nevertheless, the capacity to support microcrustaceans was higher in the ED than CD treatment, as only rotifers survived the whole experiment in the CD treatment.

Hobbie et al. (1999) performed an experiment in order to address the importance of autotrophic and heterotrophic prey for zooplankton in a clearwater arctic lake. Supported only by allochthonous DOC, added at the beginning of the experiment, ciliates, rotifers and copepod nauplii died within $20 \mathrm{~d}$. In the treatment exposed to ambient light, the zooplankton community remained abundant and productive. The partial (but not complete) independence of the pelagic food web from phytoplankton production is well documented for freshwater ecosystems receiving high amounts of allochthonous material. Comprehensive compilations of studies report that allochthonous carbon plays a large role in the diet of metazooplankton (Hessen 1998, Sarvala et al. 1999). The effect of humic DOC on metazooplankton can be seen, for instance, in the increased abundance of zooplankton relative to phyto- 
plankton along a gradient of increasing humic content (Sarvala et al. 1999). Moreover, an experiment by Salonen \& Hammar (1986) demonstrated the importance of DOC to zooplankton, by showing that microcrustaceans can grow in filtered lake water and resist several weeks of darkness. Our experiment showed similar results, but for a much longer time (up to $1.5 \mathrm{yr}$ ).

The contribution of allochthonous OM to zooplankton can be even more noticeable in natural environments than observed in our experiment. There are 2 factors that make our results conservative with respect to bioavailability of 'aged' OM (thus without any input of recent photosynthesis products) with turnover times greater than $1 \mathrm{yr}$, regardless of water type: (1) Photochemical processes acting on large recalcitrant molecules are important in aquatic ecosystems in general. Allochthonous DOM (Lindell et al. 1995, Tranvik \& Bertilsson 2001) becomes labile through photochemical breakdown and transformation following exposure to solar radiation. (2) Fresh terrigenous material entering lakes is important for the heterotrophic food web. Since we had no water exchange in the cylinders, a continuous input of 'new' allochthonous OM was lacking, limiting bacterial growth (Tranvik 1998).

\section{CONCLUSIONS}

We have shown that zooplankton are able to grow independently from actively photosynthesizing phytoplankton or other sources of 'fresh' autochthonous OM for a period as long as $1.5 \mathrm{yr}$. Regardless of differences among lakes, our results suggest that organic carbon other than that originating from recent particulate and dissolved algal production can reach zooplankton. The trophic pathway allochthonous OM-microbial loopmetazooplankton (Salonen \& Hammar 1986, Jones 1992), which receives no input of phytoplankton particulate OM or exudates, does not exist only as a concept. Detrital DOM present in the water seems to be enough to fuel higher trophic levels of plankton in a broad range of lakes, even on time scales $>1$ yr. Nutrients and DOC content may be the key factors influencing the transfer of older detrital organic carbon through the microbial food web and finally to metazooplankton in lakes. Our study thus shows that the microbial loop, based on allochthonous or 'aged' autochthonous DOM, can act as a link from DOM to metazooplankton, even though the bacterial growth efficiency is supposed to be very low in oligotrophic and humic lakes (Felip et al. 1996, del Giorgio \& Cole 1998). These results are in agreement with studies using stable isotopes and showing a significant incorporation of terrestrial carbon into zooplankton in oligotrophic and humic lakes.
Acknowledgements. This work was supported by grants from the Brazilian Research Council (CNPq) to C.D., from the Brazilian Post-graduate Agency (CAPES) to K.G., from the Swedish Research Council (VR) to W.G. and from Marie Curie (individual fellowship) to A.M.A. We thank E. Kritzberg and 2 anonymous reviewers for commenting on a previous version of this manuscript.

\section{LITERATURE CITED}

Almestrand A, Lundqvist C (1983) Vombsjön-faktasammanställning. Länsstyrelsen Malmöhus län. Malmö County Administrative Board, Malmö

Bengtsson R (1993) Sjöarnas tillstånd I Kronobergs län. Miljövårdsenheten I Växjö, Länsstyrelsen Kronobergs län. Kronoberg County Administrative Board, Växjö

Bergvall J (1992) Länets sjöar: areal, avrinningsområde, djupförhållanden och vattenföring i Kronobergs läns sjöar. Länsstyrelsen Kronobergs län. Kronoberg County Administrative Board, Växjö

Bertilsson S, Jones JBJ (2003) Supply of dissolved organic matter to aquatic ecosystems: autochthonous sources. In: Findlay SEG, Sinsabaugh RL (eds) Aquatic ecosystems: interactivity of dissolved organic matter. Academic Press, San Diego, CA, p 3-24

Biddanda B, Ogdahl M, Cotner J (2001) Dominance of bacterial metabolism in oligotrophic relative to eutrophic waters. Limnol Oceanogr 46:730-739

Burns CW, Schallenberg M (2001) Calanoid copepods vs. cladocerans: consumer effects on protozoa in lakes of different trophic status. Limnol Oceanogr 46:1558-1565

Cole JJ (1999) Aquatic microbiology for ecosystem scientists: new and recycled paradigms in ecological microbiology. Ecosystems 2:215-225

del Giorgio PA, Cole JJ (1998) Bacterial growth efficiency in natural aquatic systems. Annu Rev Ecol Syst 29:503-541

del Giorgio P, Davis J (2003) Patterns in dissolved organic matter lability and comsumption across aquatic ecosystems. In: Findlay SEG, Sinsabaugh RL (eds) Aquatic ecosystems: interactivity of dissolved organic matter. Academic Press, San Diego, CA, p 399-424

del Giorgio P, Peters RH (1994) Patterns in planktonic P:R ratios in lakes: influence of lake trophy and dissolved organic carbon. Limnol Oceanogr 39:772-787

del Giorgio P, Bird DF, Prairie YT, Planas D (1996) Flow cytometric determination of bacterial abundance in lake plankton with the green nucleic acid stain SYTO 13. Limnol Oceanogr 41:783-789

Dumont HJ, Van de Velde I, Dumont S (1975) The dry weight estimate of biomass in a selection of Cladocera, Copepoda and Rotifera from the plankton, periphyton and benthos of continental waters. Oecologia 19:75-97

Felip M, Pace ML, Cole JJ (1996) Regulation of planktonic bacterial growth rates: the effects of temperature and resources. Microb Ecol 31:15-28

Fenchel T (1982) Ecology of heterotrophic microflagellates. II. Bioenergetics and growth. Mar Ecol Prog Ser 8:225-231

Fenchel T, Finlay BJ (1983) Respiration rates in heterotrophic, free-living protozoa. Microb Ecol 9:99-122

Grey J, Jones RI, Sleep D (2001) Seasonal changes in the importance of the source of organic matter to the diet of zooplankton in Loch Ness, as indicated by stable isotope analysis. Limnol Oceanogr 46:505-513

Gulati RD, DeMott WR (1997) The role of food quality for zooplankton: remarks on the state-of-the-art, perspectives and priorities. Freshw Biol 38:753-768 
Hessen DO (1998) Food webs and carbon cycling in humic lakes. In: Hessen DO, Tranvik L (eds) Aquatic humic substances: ecology and biogeochemistry. Springer-Verlag, Berlin, p 285-315

Hobbie JE, Bahr M, Rublee PA (1999) Controls on microbial food webs in oligotrophic arctic lakes. Arch Hydrobiol Spec Issues Adv Limnol 54:61-76

Imai A, Fukushima T, Matsushige K, Kim YH (2001) Fractionation and characterization of dissolved organic matter in a shallow eutrophic lake, its inflowing rivers, and other organic matter sources. Water Res 35:4019-4028

Jansson M (1998) Nutrient limitation and bacteria-phytoplankton interactions in humic lakes. In: Hessen DO, Tranvik LJ (eds) Aquatic humic substances: ecology and biogeochemistry. Springer-Verlag, Berlin, p 178-195

Jansson M, Bergström AK, Blomqvist P, Isaksson A, Jonsson A (1999) Impact of allochthonous organic carbon on microbial food web carbon dynamics and structure in Lake Örträsket. Arch Hydrobiol 144:409-428

Jespersen AM, Christoffersen K (1987) Measurements of chlorophyll-a from phytoplankton using ethanol as extraction solvent. Arch Hydrobiol 109:445-454

Jones RI (1992) The influence of humic substances on lacustrine planktonic food-chains. Hydrobiology 229:73-91

Jones RI (2000) Mixotrophy in planktonic protists: an overview. Freshw Biol 45:219-226

Jonsson A, Meili M, Bergström AK, Jansson M (2001) Wholelake mineralization of allochthonous organic carbon in a large humic lake (Örtrösket, N. Sweden). Limnol Oceanogr 46:1691-1700

Karlsson J, Jonsson A, Jansson M (2001) Bacterioplankton production in lakes along an altitude gradient in the subarctic north of Sweden. Microb Ecol 42:372-382

Karlsson J, Jansson M, Jonsson A (2002) Similar relationships between pelagic primary and bacterial production in clearwater and humic lakes. Ecology 83:2902-2910

Kritzberg ES, Cole JJ, Pace ML, Granéli W, Bade DL (2004) Authochthonous versus allochthonous carbon sources of bacteria: Results from whole-lake ${ }^{13} \mathrm{C}$ addition experiments. Limnol Oceanogr 49:588-596

Laybourn-Parry J, Walton M, Young J, Jones RI, Shine A (1994) Protozooplankton and bacterioplankton in a large oligotrophic lake-Loch-Ness, Scotland. J Plankton Res 16:1655-1670

Leenheer JA (1994) Chemistry of dissolved organic-matter in rivers, lakes, and reservoirs. Environmental chemistry of lakes and reservoirs. Adv Chem Ser 237:195-221

Lindell MJ, Granéli HW, Tranvik LJ (1995) Enhanced bacterial growth in response to photochemical transformation of dissolved organic matter. Limnol Oceanogr 40:195-199

Editorial responsibility: John Dolan, Villefranche-sur-Mer, France
Pålsson C, Daniel C (2004) Effects of prey abundance and light intensity on nutrition of a mixotrophic flagellate and its competitive relationship with an obligate heterotroph. Aquat Microb Ecol 36:247-256

Perdue M (1998) Chemical composition, structure, and metal binding properties. In: Hessen DO, Tranvik L (eds) Aquatic humic substances: ecology and biogeochemistry. Springer-Verlag, Berlin, p 41-61

Peuravouri J, Pihlaja K (1999) Structural characterization of humic substances. In: Keskitalo J, Eloranta P (eds) Limnology of humic waters. Backhuys Publishers, Leiden, p 22-39

Pourriot R (1977) Food and feeding habitats of Rotifera. Arch Hydrobiol Beih Ergebn Limnol 8:243-260

Ruttner-Kolisko A (1977) Suggestions for biomass calculation of planktonic rotifers. Arch Hydrobiol Beih Ergebn Limnol 8:71-76

Salonen K, Hammar T (1986) On the importance of dissolved organic matter in the nutrition of zooplankton in some lake waters. Oecologia 68:246-253

Sarvala J, Kankaala P, Zingel P, Arvola L (1999) Food webs of humic waters - zooplankton. In: Keskitalo J, Eloranta P (eds) Limnology of humic waters. Backhuys Publishers, Leiden, p 173-191

Shaw P (1994) The effect of $\mathrm{pH}$, dissolved humic substances, and ionic composition on the transfer of iron and phosphate to particulate size fractions in epilimnetic waters. Limnol Oceanogr 39:1734-1743

Sinsabaugh RL, Foreman CM (2003) Integrating dissolved organic matter metabolism and microbial diversity: an overview of conceptual models. In: Findlay SEG, Sinsabaugh RL (eds) Aquatic ecosystems: interactivity of dissolved organic matter. Academic Press, San Diego, CA, p 425-454

Smith DC, Azam F (1992) A simple economical method for measuring bacterial protein synthesis rate in seawater using ${ }^{3} \mathrm{H}$-leucine. Mar Microb Food Webs 6:107-114

Telesh IV, Rahkola M, Viljanen M (1998) Carbon content of some freshwater rotifers. Hydrobiology 388:355-360

Tranvik L (1998) Degradation of dissolved organic matter in humic waters by bacteria. In: Hessen DO, Tranvik L (eds) Aquatic humic substances: ecology and biogeochemistry. Springer-Verlag, Berlin, p 259-284

Tranvik LJ, Bertilsson S (2001) Contrasting effects of solar UV radiation on dissolved organic sources for bacterial growth. Ecol Lett 4:458-463

Utermöhl H (1958) Zur Verrvollkommnung der quantitativen Phytoplankton-Methodik. Mitt Int Ver Theor Angew Limnol 9:1-38

Wetzel RG, Likens GE (2003) Limnological analyses, 3rd edn. Springer, New York

Submitted: May 12, 2004; Accepted: December 2, 2004

Proofs received from author(s): January 27, 2005 